\title{
Alpinia cearulea (R.Br.) Benth Leaf Extracts Inhibit the Growth of a Panel of Bacterial Pathogens
}

\author{
Lindiwe Nomathemba Mpala', Getmore Rumbudzai Chikowe', lan Edwin Cock 1,2,* \\ 'School of Natural Sciences, Griffith University, 170 Kessels Rd, Nathan, Brisbane, Queensland 4111, AUSTRALIA. \\ ¿Environmental Futures Research Institute, Griffith University, 170 Kessels Rd, Nathan, Brisbane, Queensland 4111, AUSTRALIA.
}

\begin{abstract}
Introduction: Alpinia caerulea is a perennial herb which grows in coastal regions of Australia. All parts of this species are consumed as a bushfood. Furthermore, A. caerulea is taxonomically related to several plant species with well documented antimicrobial properties. Despite this, A. caerulea leaf solvent extractions have not previously been examined for antibacterial properties. Methods: The antimicrobial activity of $A$. caerulea leaf solvent extractions was investigated by disc diffusion and growth time course assays against a panel of pathogenic bacteria. The growth inhibitory activity was quantified by MIC determination. Toxicity was determined using the Artemia franciscana nauplii bioassay. Results: Methanolic and aqueous A. caerulea leaf extracts inhibited the growth of a range of gram positive and gram negative bacterial species. The methanolic extract was generally a more potent growth inhibitor than the aqueous extract. The methanolic and aqueous extracts were particularly potent inhibitors of $S$. marcenscens growth, with $\mathrm{MIC}$ values as low as $188 \mu \mathrm{g} / \mathrm{mL}$ for the methanolic extract. P. mirabilis (MICs of 785 and $976 \mu \mathrm{g} / \mathrm{mL}$ for the methanolic and aqueous extracts respectively) and $K$. pneumoniae growth (MICs of 1167 and $924 \mu \mathrm{g} / \mathrm{mL}$ for the methanolic and aqueous extracts respectively) were also particularly susceptible to the $A$. caerulea leaf extracts. The antibacterial activity of the methanolic and aqueous $A$. caerulea leaf extracts was further
\end{abstract}

\section{INTRODUCTION}

Alpinia caerulea (R.Br.) Benth. (family Zingiberaceae; synonym Hellenia caerulea R.Br.; commonly known as Australian native ginger and blue berry ginger) is a perennial herb which grows in the shaded understorey of rainforests and wet shlerophyll forests in eastern coastal regions of Australia, extending from Sydney to the tropical regions of far northern Queensland. ${ }^{1}$ A. caerulea grows up to $2 \mathrm{~m}$ tall, with only the leaves growing above ground level (as with other Zingiberaceae spp., the stem grows below ground level). The sessile leaves (Figure 1a and Figure 1b) grow to approximately $40 \mathrm{~cm}$ long and $10 \mathrm{~cm}$ wide. Creamy white flowers (Figure 1c) develop into dark blue globular fruit capsules approximately 10-15 mm diameter (Figure 1d). The flesh inside the fruit is white and contains a single black seed. The first Australians used A. caerulea as a nutritious, flavoursome snack. The fruit pulp was consumed directly and the seeds were discarded. Alternatively, the fruit can be dried and ground and used as a flavouring agent. Whilst the fruit is most often cited as a bushfood, all parts of the plant are edible and have been used by Australian Aborigines as well as early colonial settlers in their cuisine. The leaves can be dried, ground and used both as a spice and as an herbal infusion. Wrapping food in the leaves imparts a gingery flavour and was sometimes used in traditional cookery. The centres of the new shoots have a distinct gingery flavour and can be used fresh in cooking as a ginger substitute. The below ground parts (roots and stem) have a stronger, more earthy ginger flavour and are used sparingly in cooking.

We were unable to find reports of the use of $A$. caerulea by Australian Aborigines as a traditional medicine. Instead, it appears to have been more valued as a culinary plant. However, the first Australians passed on traditional knowledge orally and there is a lack of written records from the early days of European colonisation which document the use investigated by growth time course assays which showed significant growth inhibition in cultures of $S$. marcenscens and $P$. mirabilis within $1 \mathrm{~h}$ of exposure. All extracts were determined to be nontoxic in the Artemia franciscana nauplii bioassay, indicating their safety for internal use as well as for topical uses. Conclusion: The lack of toxicity of the $A$. caerulea leaf extracts and their growth inhibitory bioactivity against a panel of pathogenic bacteria indicate their potential in the development of antibiotic agents. Key words: Alpinia caerulea, Zingiberaceae, Native ginger, Blue berry ginger, Rheumatoid arthritis, Ankylosing spondylitis, Antibacterial activity, Medicinal plants.

Correspondence:

Dr. Ian Edwin Cock

'School of Natural Sciences, Griffith University, 170 Kessels Rd, Nathan, Brisbane, Queensland 4111, AUSTRALIA.

${ }^{2}$ Environmental Futures Research Institute, Griffith University, 170 Kessels Rd, Nathan, Brisbane, Queensland 4111, AUSTRALIA.

Phone no: +61737357637

E-mail: I.Cock@griffith.edu.au

DOI: $10.5530 /$ pc.2018.4.31 of plants for therapeutic purposes. Therefore, much of the first Australian's traditional knowledge of medicinal plants has been lost. It is therefore possible that the first Australians may also have had therapeutic (as well as culinary) uses for A. caerulea. Notably, A. caerulea shares close taxonomic relationships with several other culinary plants from other regions of the world with well-established therapeutic properties. It is taxonomically related to Alpinia galangal (galangal), Zingiber officinale (common ginger), Curcuma longa (turmeric) and cardamom (Elettaria spp., Amomum spp.). All of these plants are members of family Zingiberaceae and all have well documented therapeutic properties. ${ }^{2-5}$ It is possible that A. caerulea may contain similar phytochemicals and have similar therapeutic properties.

Several interesting phytochemical components have been identified in A. cearulea extracts. In particular, 2 diterpenoids were isolated from A. cearulea fruit and identified as zerumin A (Figure 1e) and (E)-8(17), 12-labdadiene-15,16-dial (Figure 1f). ${ }^{6}$ That study focussed on the antiangiogenic activity of $A$. cearulea extracts and the isolated compounds and did not screen them for the ability to inhibit bacterial growth. Furthermore, we were unable to find any other studies examining the antibacterial properties of these compounds. A different study examined the phytochemistry and antibacterial properties of extracts prepared from the rhizome of the related species Alpinia pahangensis Ridley. That study identified 2 different diterpenoids which were structurally similar to the A. cearulea fruit diterpenoids. Indeed, pahangensin B is a methylated form of zerumin $A$ and pahangensin $A$ is a dimeric form of pahangensin B. Interestingly that study tested pahangensin A and pahangensin B for antibacterial activity and reported potent growth inhibition. Indeed, pahangensin A was reported to have similar antibacterial potency as pure streptomycin and chloramphenicol against $S$. aureus and $B$. subtilis and substantially better potency than penicillin against 


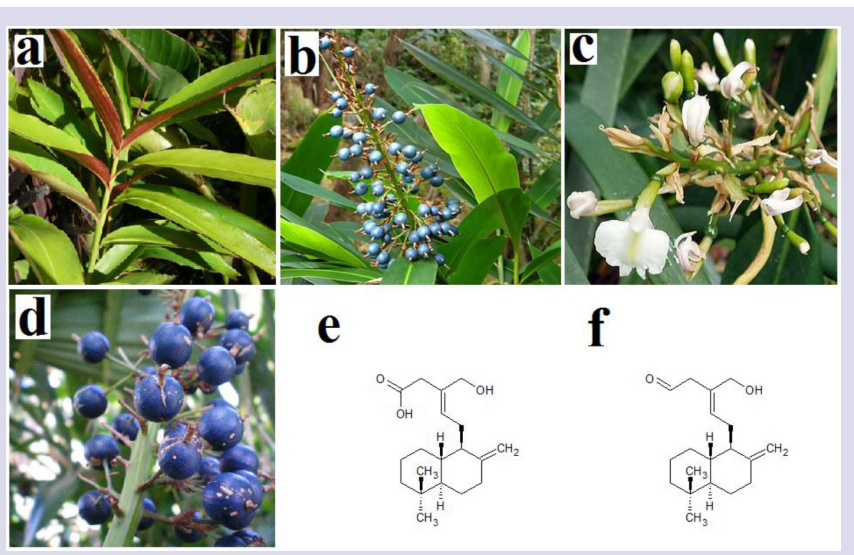

Figure 1: A. cearulea (a) leaves, (b) whole plant, (c) flowers and (d) fruit, as well as the chemical structures of the diterpenoid components (e) zerumin $A$, (f) (E)-8(17),12-labdadiene-15,16-dial.

B. cereus. Both $A$. pahangensis diterpenoids only inhibited gram positive bacterial growth and had no effect on gram negative bacteria. Despite these promising studies, examination of the antibacterial properties of A. cearulea extracts and isolated compounds is lacking. The current report was undertaken to screen $A$. cearulea leaf extracts for growth inhibitory properties against a panel of pathogenic bacteria.

\section{MATERIALS AND METHODS}

\section{Plant collection and extraction}

Alpinia cearulea (R.Br.) Benth. leaves were obtained from and identified by Philip Cameron, senior botanic officer, Mt Cootha Botanical Gardens, Brisbane, Australia. Leaf samples were dried in a Sunbeam food dehydrator and stored at $-30^{\circ} \mathrm{C}$. Prior to use, the dried leaves was freshly ground to a coarse powder and $1 \mathrm{~g}$ quantities were weighed into separate tubes. A volume of $50 \mathrm{~mL}$ methanol, sterile deionised water, ethyl acetate, chloroform or hexane was added to individual tubes and extracted for $24 \mathrm{~h}$ at $4^{\circ} \mathrm{C}$ with gentle shaking. All solvents were obtained from Ajax, Australia and were AR grade. The extracts was filtered through filter paper (Whatman No. 54) under vacuum, followed by drying by rotary evaporation in an Eppendorf concentrator 5301. The resultant pellets were dissolved in $10 \mathrm{~mL}$ sterile deionised water (containing 1\% DMSO). The extracts were passed through $0.22 \mu \mathrm{m}$ filter (Sarstedt) and stored at $4^{\circ} \mathrm{C}$ until use.

\section{Qualitative phytochemical studies}

Phytochemical analysis of the A. cearulea leaf extracts for the presence of saponins, phenolic compounds, flavonoids, phytosteroids, triterpenoids, cardiac glycosides, anthraquinones, tannins and alkaloids was conducted by previously described assays. ${ }^{8-10}$

\section{Antibacterial screening Test microorganisms}

All media was supplied by Oxoid Ltd., Australia. Reference strains of Klebsiella pneumoniae (ATCC31488), Escherichia coli (ATCC 25922) and Proteus mirabilis (ATCC21721) were purchased from American Tissue Culture Collection, USA. Clinical isolate microbial strains of Aeromonas hydrophilia, Alcaligenes feacalis, Bacillus cereus, Citrobacter freundii, Pseudomonas fluorescens, Salmonella newport, Serratia marcescens, Shigella sonneii, Staphylococcus aureus, Staphylococcus epidermidis and Streptococcus pyonenes were obtained from Ms Michelle Mendell and Ms Jane Gifkins, Griffith University. All stock cultures were subcultured and maintained in nutrient broth at $4^{\circ} \mathrm{C}$.

\section{Evaluation of antimicrobial activity}

Antimicrobial activity of all plant extracts was determined using a modified disc diffusion assay. ${ }^{11-13}$ Briefly, $100 \mu \mathrm{L}$ of each bacterial culture was grown in $10 \mathrm{~mL}$ of fresh nutrient broth until they reached a count of $\sim 10^{8}$ cells $/ \mathrm{mL}$. A volume of $100 \mu \mathrm{L}$ of the bacterial suspension was spread onto nutrient agar plates and extracts were tested for antibacterial activity using $5 \mathrm{~mm}$ sterilised filter paper discs. Discs were infused with $10 \mu \mathrm{L}$ of the plant extracts, allowed to dry and placed onto the inoculated plates. The plates were allowed to stand at $4^{\circ} \mathrm{C}$ for $2 \mathrm{~h}$ before incubation at $30^{\circ} \mathrm{C}$ for $24 \mathrm{~h}$. The diameters of the inhibition zones were measured to the closest whole millimetre. Each assay was performed in at least triplicate. Mean values $( \pm$ SEM) are reported in this study. Standard discs of ampicillin $(10 \mu \mathrm{g})$ were obtained from Oxoid, Australia and were used as positive controls to compare antibacterial activity. Filter discs infused with $10 \mu \mathrm{L}$ of distilled water were used as a negative control.

\section{Minimum inhibitory concentration (MIC) determination}

The minimum inhibitory concentration (MIC) of each extract against susceptible bacteria was determined as previously described. ${ }^{14-15}$ Briefly, the $A$. cearulea leaf extracts were diluted in deionised water and tested across a range of concentrations. Discs were infused with $10 \mu \mathrm{L}$ of the test dilutions, allowed to dry and placed onto inoculated plates. The assay was completed as outlined above and graphs of the zone of inhibition versus concentration were plotted for each extract. Linear regression was used to determine the MIC values of each extract.

\section{Bacterial growth time course assay}

Bacterial growth time course studies were performed as previously described. ${ }^{16}$ Briefly, $3 \mathrm{~mL}$ of Proteus mirabilis (ATCC21721) and S. marcenscens in nutrient broth were individually added to $27 \mathrm{~mL}$ nutrient broth containing $3 \mathrm{~mL}$ of $10 \mathrm{mg} / \mathrm{mL}$ methanolic or aqueous plant extract to give a final concentration of $1000 \mu \mathrm{g} / \mathrm{mL}$ in the assay. The tubes were incubated at $30^{\circ} \mathrm{C}$ with gentle shaking. The optical density was measured hourly at $550 \mathrm{~nm}$ for a $6 \mathrm{~h}$ incubation period. Control tubes were incubated under the same conditions but without the extract. All assays were performed in triplicate.

\section{Toxicity screening \\ Reference toxin for toxicity screening}

Potassium dichromate $\left(\mathrm{K}_{2} \mathrm{Cr}_{2} \mathrm{O}_{7}\right)$ (AR grade, Chem-Supply, Australia) was prepared as a $4 \mathrm{mg} / \mathrm{mL}$ solution in distilled water and was serially diluted in artificial seawater for use in the Artemia franciscana nauplii bioassay.

\section{Artemia franciscana nauplii toxicity screening}

Toxicity was tested using an adapted Artemia franciscana nauplii lethality assay. ${ }^{17-19}$ Briefly, $400 \mu \mathrm{L}$ of seawater containing approximately 58 (mean $57.6, \mathrm{n}=75, \mathrm{SD} 11.6)$ A. franciscana nauplii were added to wells of a 48 well plate and immediately used for bioassay. A volume of $400 \mu \mathrm{L}$ of diluted plant extracts or the reference toxin were transferred to the wells and incubated at $25 \pm 1^{\circ} \mathrm{C}$ under artificial light (1000 Lux). A $400 \mu \mathrm{L}$ seawater negative control was run in triplicate for each plate. All treatments were performed in at least triplicate. The wells were checked at regular intervals and the number of dead counted. The nauplii were considered dead if no movement of the appendages was detected within $10 \mathrm{sec}$. After $24 \mathrm{~h}$, all nauplii were sacrificed and counted to determine the total \% mortality per well. The $\mathrm{LC}_{50}$ with $95 \%$ confidence limits for each treatment was determined using probit analysis. 


\section{Statistical analysis}

Data are expressed as the mean \pm SEM of at least three independent experiments. One way ANOVA was used to calculate statistical significance between control and treated groups with a $P$ value $<0.01$ considered to be statistically significant.

\section{RESULTS}

\section{Liquid extraction yields and qualitative phytochemical screening}

Extraction of $1 \mathrm{~g}$ of dried and powdered A. cearulea leaf with solvents of varying polarity yielded dried extracts ranging from $54 \mathrm{mg}$ (hexane extract) to $158 \mathrm{mg}$ (methanol extract) (Table 1$)$. The aqueous (126 mg) and chloroform extracts $(117 \mathrm{mg})$ also yielded relatively high levels of extracted materials. The dried extracts were resuspended in $10 \mathrm{~mL}$ of deionised water (containing 1\% DMSO), resulting in the extract concentrations shown in Table 1.

Qualitative phytochemical studies showed that the higher polarity methanol and water solvents extracted the greatest diversity and highest levels of phytochemicals. Both contained high levels of phenolics and flavonoids and low-moderate levels of saponins, triterpenoids and tannins. The ethyl acetate extract contained similar phytochemical classes, albeit generally at lower levels. Interestingly, despite extracting relatively large amounts of material, the chloroform and hexane extracts were devoid of all classes of phytochemicals screened. Due to their nonpolar nature, these extracts would be expected to contain high levels of lipids, hydrocarbons etc. As our qualitative phytochemical studies did not screen for these compounds, they were not detected and other techniques are required to further examine the nature of these nonpolar components.

\section{Antimicrobial activity}

To determine the growth inhibitory activity of the A. cearulea leaf extracts against the panel of pathogenic bacteria, aliquots $(10 \mu \mathrm{L})$ of each extract were screened in the disc diffusion assay. The methanolic and aqueous A. cearulea leaf extracts inhibited 3 of the $10(30 \%)$ gram negative bacterial species screened in this study (Figure 2). The methanolic A. cearulea leaf extract was generally a more potent growth inhibitor than the aqueous extract against most bacterial species (as assessed by the sizes of the zones of inhibition). The inhibition of $S$. marcenscens growth inhibition was particularly noteworthy, with the methanolic and aqueous extracts producing $10.0 \pm 1.0$ and $8.6 \pm 0.6 \mathrm{~mm}$ respectively. This inhibition was particularly noteworthy compared to the inhibition by the ampicillin control $(10 \mu \mathrm{g}$ : inhibition zones of $6.6 \pm 0.3 \mathrm{~mm})$. P. mirabilis $(8.3 \pm 0.3 \mathrm{~mm}$ and $7.9 \pm 0.6 \mathrm{~mm}$ for the methanolic and aqueous extracts respectively) and $K$. pneumoniae growth $(7.3 \pm 0.3 \mathrm{~mm}$ and $7.5 \pm 0.5 \mathrm{~mm}$ for the methanolic and aqueous extracts respectively) were also susceptible to inhibition by the $A$. cearulea leaf extracts. The ethyl acetate extract also inhibited the growth of the same bacteria, albeit generally with substantially smaller inhibition zones than were recorded for methanolic and aqueous extracts. The chloroform and hexane extracts were generally devoid of growth inhibitory activity.

Gram positive bacteria were also susceptible to the A. cearulea leaf extracts (Figure 3). Indeed, a higher proportion of the gram positive bacteria screened were susceptible compared to the gram negative bacteria. Of the 4 gram positive bacterial strains tested, 3 (75\%) were inhibited by both the methanolic and aqueous A. cearulea leaf extracts. With the exception of $S$. pyogenes, all of the susceptible gram positive bacteria were also inhibited by the ethyl acetate $A$. cearulea leaf extract. The chloroform and hexane extracts were completely devoid of bacterial growth inhibitory activity against all gram positive bacterial species.

The antimicrobial efficacy was further quantified by determining the MIC values for each extract against the microbial species which were determined to be susceptible. The methanolic and aqueous $A$. cearulea leaf extracts were potent growth inhibitors of several bacterial species (as judged by MIC; Table 2). S. marcenscens was the most susceptible bacteria to the $A$. cearulea leaf extracts, with an MIC value of $188 \mu \mathrm{g} / \mathrm{mL}$ $(<2 \mu \mathrm{g}$ infused into the disc) recorded for the methanolic extract. The aqueous and ethyl acetate extracts were also potent $S$. marcenscens growth inhibitors, with MIC values of 405 and $846 \mu \mathrm{g} / \mathrm{mL}$ respectively. $P$. mirabilis and $K$. pneumoniae were also highly susceptible to the methanolic and aqueous A. cearulea leaf extracts, generally with MIC values $<1000 \mu \mathrm{g} / \mathrm{mL}$. As $P$. mirabilis infection is a common cause of

Table 1: The mass of dried extracted material, the concentration after resuspension in deionised water and qualitative phytochemical screenings of the $A$. cearulea leaf extracts.

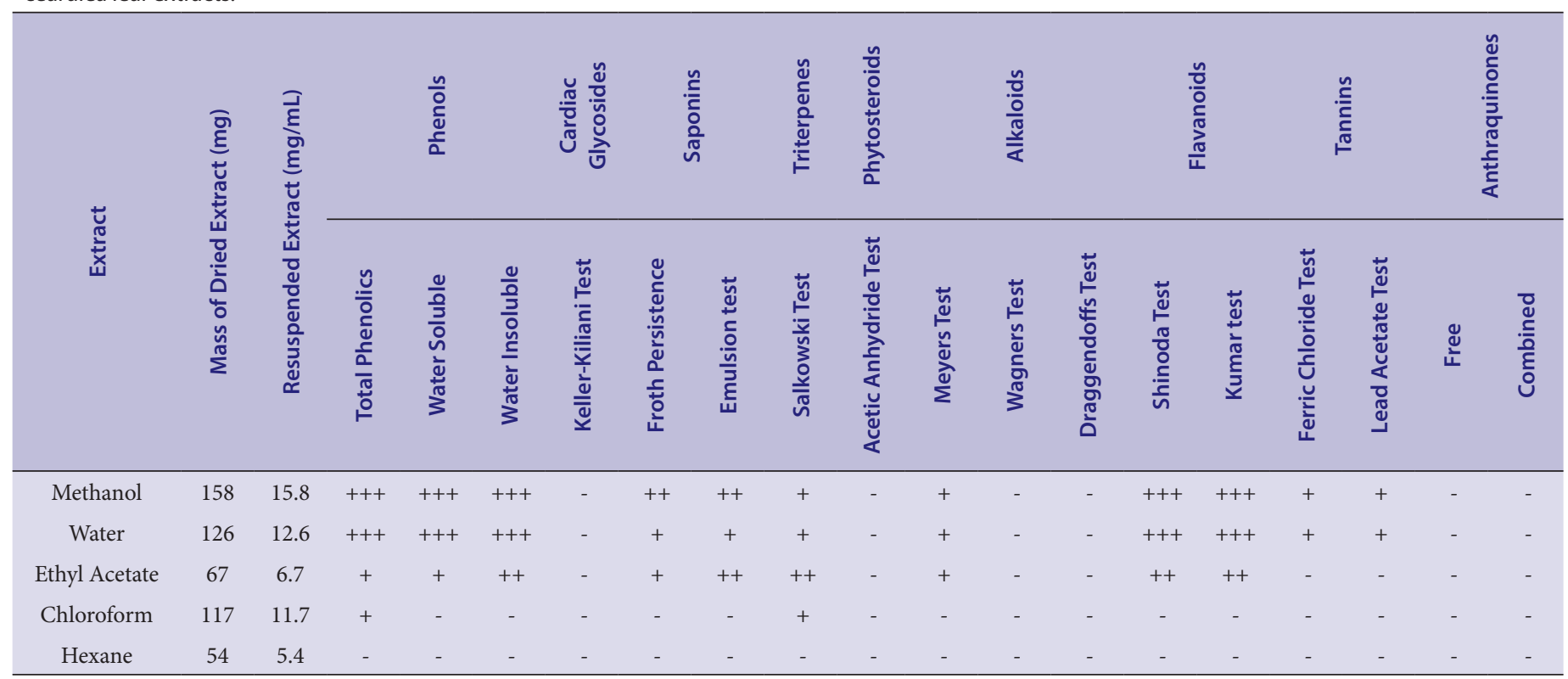

+++ indicates a large response; ++ indicates a moderate response; + indicates a minor response; - indicates no response in the assay. 


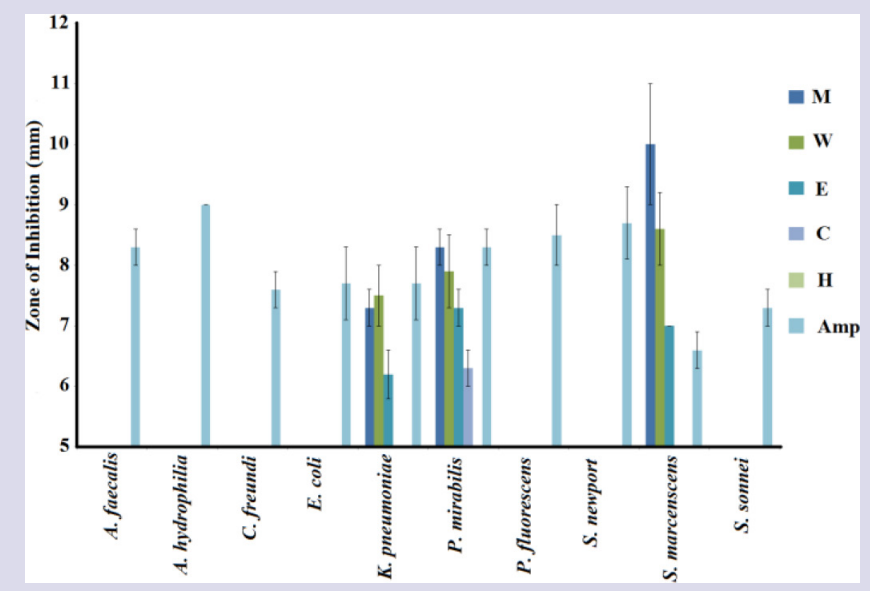

Figure 2: Growth inhibitory activity of $A$. cearulea leaf extracts against the gram negative bacterial species. $M=$ methanolic extract; $\mathrm{W}=$ aqueous extract; $\mathrm{E}=$ ethyl acetate extract; $\mathrm{C}=$ chloroform extract; $\mathrm{H}=$ hexane extract; $\mathrm{Amp}=$ ampicillin $(10 \mu \mathrm{g})$ control. All determinations were performed in at least triplicate and the results are expressed as mean zones of inhibition $(\mathrm{mm}) \pm \mathrm{SEM}$.

Table 2: Minimum bacterial growth inhibitory concentration $(\mu \mathrm{g} / \mathrm{mL})$ of the A. cearulea leaf extracts.

\begin{tabular}{cccccc}
\hline Bacteria & M & W & E & C & H \\
\hline $\begin{array}{c}\text { Gram negative } \\
\text { bacteria }\end{array}$ & & & & & \\
A. faecalis & - & - & - & - & - \\
A. hydrophilia & - & - & - & - & - \\
C. freundi & - & - & - & - & - \\
$\quad$ E. coli & - & - & - & - & - \\
K. pneumoniae & 1167 & 924 & 1255 & - & - \\
P. mirabilis & 785 & 976 & 1085 & 2038 & - \\
P. fluroscens & - & - & - & - & - \\
S. newport & - & - & - & - & - \\
S. marcenscens & 188 & 405 & 846 & - & - \\
S. sonnei & - & - & - & - & - \\
Gram positive & & & & & \\
bacteria & & & & & \\
B. cereus & 1078 & 826 & 1140 & - & - \\
S. aureus & 1855 & 1450 & 3408 & - & - \\
S. epidermidis & - & - & - & - & - \\
S. pyogenes & 2275 & 1638 & - & - & - \\
\hline
\end{tabular}

Numbers indicate the mean MIC and $\mathrm{LC}_{50}$ values of triplicate determinations. indicates no inhibition. $\mathrm{M}=$ methanolic extract; $\mathrm{W}=$ aqueous extract; $\mathrm{E}=$ ethyl acetate extract; $\mathrm{C}=$ chloroform extract $\mathrm{H}=$ hexane extract.

urinary tract infections and has also been identified as a trigger of rheumatoid arthritis, ${ }^{20-21}$ the aqueous and methanolic A. cearulea leaf extracts have potential for the prevention of these diseases in genetically susceptible individuals. Similarly, K. pneumoniae is a microbial trigger of ankylosing spondylitis. ${ }^{22-23}$ indicating the potential of the aqueous and methanolic A. cearulea leaf extracts in the prevention and treatment of this disease. The aqueous and methanolic A. cearulea leaf extracts also displayed moderate growth inhibitory activity towards the gram positive bacteria

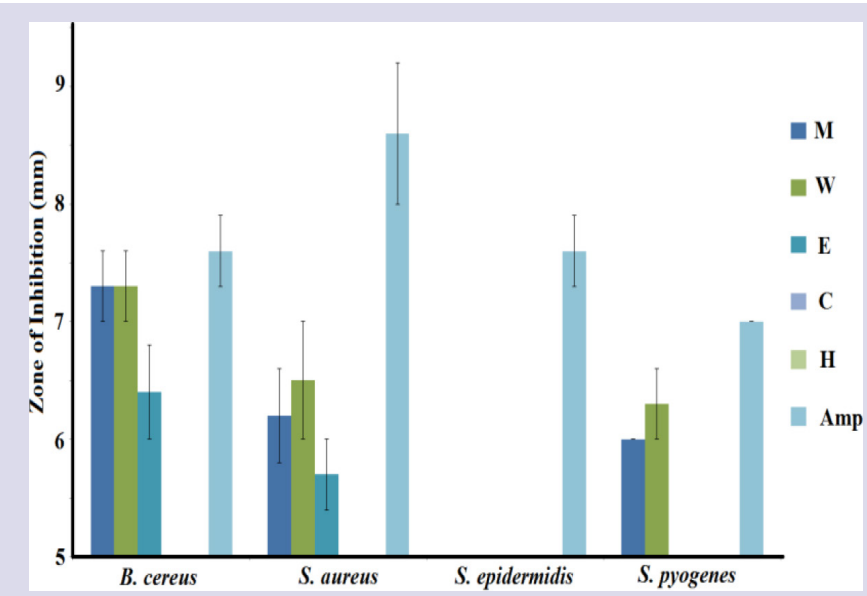

Figure 3: Growth inhibitory activity of $A$. cearulea leaf extracts against the gram positive bacterial species. $M=$ methanolic extract;

$\mathrm{W}=$ aqueous extract; $\mathrm{E}=$ ethyl acetate extract; $\mathrm{C}=$ chloroform extract; $\mathrm{H}=$ hexane extract; Amp = ampicillin $(10 \mu \mathrm{g})$ control. All determinations were performed in at least triplicate and the results are expressed as mean zones of inhibition $(\mathrm{mm}) \pm \mathrm{SEM}$.

B. cereus, S. aureus and S. pyogenes, with MIC values in the 1000-2300 $\mu \mathrm{g} / \mathrm{mL}$ range. Moderate to low growth inhibition (or no inhibition) was noted for all other extract/bacterium combinations.

\section{Bacterial growth time course assay}

The antibacterial activity of the A. cearulea leaf extracts was further investigated in the $P$. mirabilis and $S$. marcenscens by bacterial growth time course assays in the presence and absence of the A. cearulea extracts. Only the effect of the methanolic and aqueous extracts on the bacterial growth time course were evaluated as these extracts were the most potent bacterial growth inhibitors (as judged by MIC). Furthermore, the time course studies only examined the effect of the extracts on the P. mirabilis and S. marcescens as these were the most susceptible bacterial species. The starting concentration of the extract used in these assays was $1000 \mu \mathrm{g} / \mathrm{mL}$. The methanolic and aqueous A. cearulea leaf extracts significantly inhibited $P$. mirabilis (Figure 4a) and S. marcescens growth (Figure $4 \mathrm{~b}$ ) within $1 \mathrm{~h}$, indicating a rapid antimicrobial action. Whilst $P$. mirabilis growth was inhibited for $4-5 \mathrm{~h}$ of the time course, the bacteria were able to overcome this inhibition by $6 \mathrm{~h}$, with the recorded turbidity not significantly different to that of the untreated control. This indicates that the growth inhibition of these bacteria was bacteriostatic for the methanolic A. cearulea leaf extract at the concentrations tested. A similar inhibitory time course was evident for $S$. marcescens growth in the presence of aqueous $A$. cearulea extract. $S$. marcescens growth was inhibited for $4-5 \mathrm{~h}$ of the time course, although the bacterium overcame the inhibition by $6 \mathrm{~h}$. In contrast, inhibition of $S$. marcescens growth by the methanolic $A$. cearulea leaf extract was substantially more profound, with growth still significantly inhibited by the end of the $6 \mathrm{~h}$ time course study. This may indicate that the methanolic A. cearulea leaf extract has bactericidal activity against $S$. marcescens at the dose tested. Indeed, the turbidity at $6 \mathrm{~h}$ was not greatly increased from the starting turbidity.

\section{Quantification of toxicity}

The toxicity of the A. cearulea leaf extracts was initially tested in the Artemia franciscana nauplii bioassay at a concentration of $2000 \mu \mathrm{g} / \mathrm{mL}$ (Figure 5). All extracts induced low levels of mortality at $24 \mathrm{~h}$, similar to the $\%$ mortality seen for the seawater control. By $48 \mathrm{~h}$, the aqueous and 


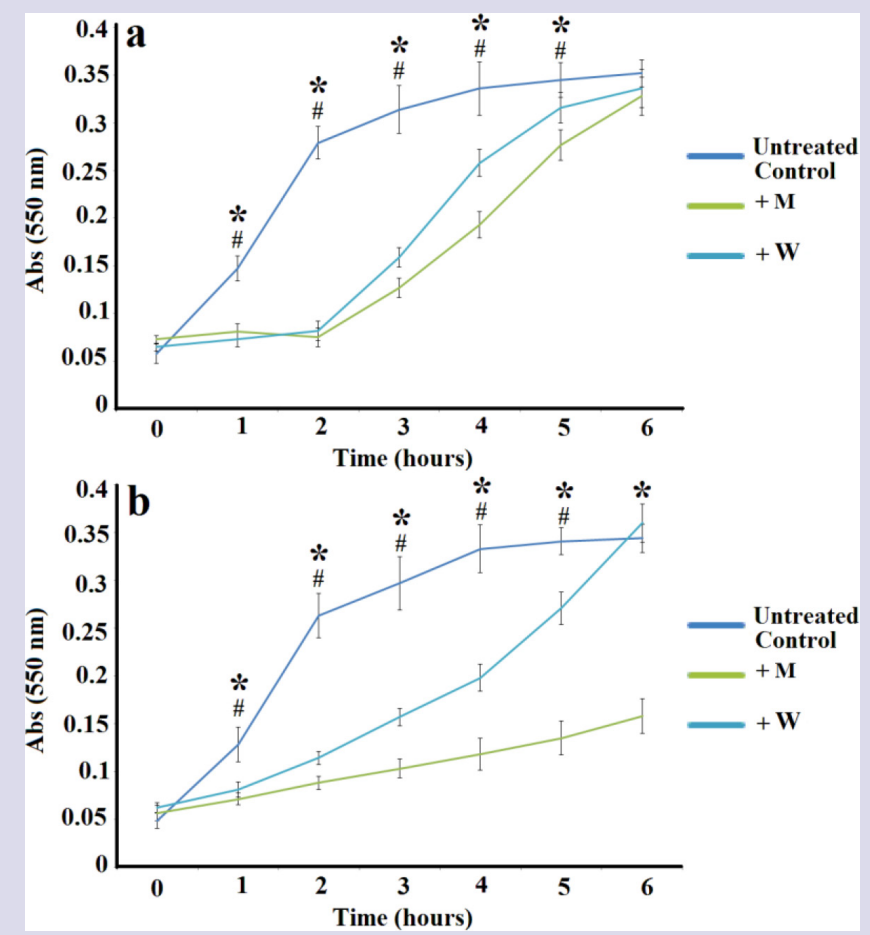

Figure 4: Bacterial growth curves for the methanolic and aqueous A. cearulea leaf extracts against (a) P. mirabilis and (b) S. marcenscens. All bioassays were performed in at least triplicate and are expressed as mean \pm SEM. ${ }^{*}=$ results that are significantly different between the growth in the presence of methanolic extract and the untreated control growth $(p<0.01)$; $\#=$ results that are significantly different between the growth in the presence of aqueous extract and the untreated control growth $(p<0.01)$

methanolic extracts had begun to induce mortality significantly higher than that in the untreated control. However, the level of mortality was still substantially $<50 \%$ toxicity at $48 \mathrm{~h}$ for all extracts. Thus, all of the A. cearulea leaf extracts were deemed to be nontoxic. Extracts with an $\mathrm{LC}_{50}>1000 \mu \mathrm{g} / \mathrm{mL}$ towards Artemia nauplii have previously been defined as being nontoxic. ${ }^{19}$ In contrast, the potassium dichromate positive control induced mortality within $4 \mathrm{~h}$ (results not shown), with $100 \%$ mortality induction seen by $24 \mathrm{~h}$.

\section{DISCUSSION}

Pharmacognostic and natural product remedies are becoming increasingly sought after in the treatment and prevention of disease due to the failure of current drug regimens to effectively treat many diseases. This study reports on the growth inhibitory properties of $A$. cearulea leaf extracts against a panel of pathogenic bacteria and on their toxicity. Both gram positive and gram negative bacteria were susceptible to the S. formosa leaf extracts, although the gram positive bacteria had greater susceptibility (as judged by the number of bacteria inhibited). Indeed, the methanolic and aqueous extracts each inhibited $75 \%$ of the gram positive bacterial species screened, compared to $30 \%$ of the gram negative bacteria. This is consistent with many previous studies with other plant species which report a greater susceptibility of gram positive bacteria towards solvent extracts for South American, ${ }^{24}$ African ${ }^{25}$ and Australian. ${ }^{26-28}$ plant extracts.

Our study examined the ability of $A$. cearulea leaf extracts to inhibit the growth of a panel of medicinally important bacterial pathogens. The methanolic and aqueous extracts were identified as being particularly

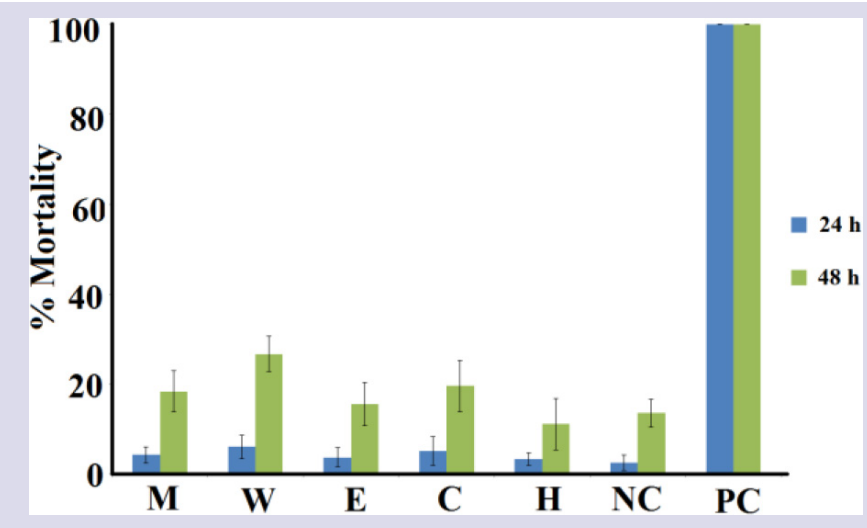

Figure 5: The lethality of the $A$. cearulea leaf extracts $(2000 \mu \mathrm{g} / \mathrm{mL})$, potassium dichromate $(1000 \mu \mathrm{g} / \mathrm{mL})$ and a seawater control. $\mathrm{M}=$ methanolic extract; $\mathrm{W}=$ aqueous extract; $\mathrm{E}=$ ethyl acetate extract; $\mathrm{C}=$ chloroform extract; $\mathrm{H}=$ hexane extract; $\mathrm{NC}=$ negative (seawater) control; $\mathrm{PC}=$ positive control $(1000 \mu \mathrm{g} / \mathrm{mL}$ potassium dichromate). All bioassays were performed in at least triplicate and are expressed as mean \pm SEM.

potent inhibitors of $S$. marcenscens growth, with MIC values of 188 and $405 \mu \mathrm{g} / \mathrm{mL}$ respectively. As $S$. marcenscens is a common cause of hospitalacquired infections, as well as urinary tract infections and wound infections, ${ }^{22}$ A. cearulea leaf extracts may provide useful leads in the treatment of these diseases. The methanolic and aqueous extracts were also potent inhibitors of $P$. mirabilis growth, with MIC values of 785 and $976 \mu \mathrm{g} / \mathrm{mL}$ respectively. As $P$. mirabilis can trigger rheumatoid arthritis in genetically susceptible individuals, ${ }^{20-21}$ these extracts have potential for the development of rheumatoid arthritis preventative therapies. The methanolic and aqueous extracts also had moderate to good K. pneumoniae growth inhibitory properties, with MIC values of 1167 and $924 \mu \mathrm{g} / \mathrm{mL}$ respectively. As K. pneumoniae can trigger ankylosing spondylitis in genetically susceptible individuals, ${ }^{22-23}$ these extracts may also be useful in the prevention of that disease. The methanolic and aqueous A. cearulea leaf extracts also were moderate inhibitors of several other bacterial pathogens. Both the aqueous and methanolic A. cearulea leaf extracts were good inhibitors of B. cereus, S. aureus and S. pyogenes growth, with MIC values generally $1000-2300 \mu \mathrm{g} / \mathrm{mL}$. As these bacteria have been implicated in a number of gastrointestinal and skin diseases, the aqueous and methanolic A. cearulea leaf extracts also may have applications in the treatment of these diseases.

Whilst a detailed investigation of the phytochemistry of the A. cearulea leaf extracts was beyond the scope of our study, qualitative screening was used to determine the classes of compounds present. Several commonalities were noted: the most potent aqueous and methanolic extracts all contained relatively high levels of phenolics and flavonoids. Many studies have reported potent antibacterial activities for a wide variety of polyphenolic compounds, including many flavonoids. ${ }^{29}$ Bioactivity driven isolation of active components is required to further identify the bioactive components and to evaluate the mechanism of bacterial growth inhibition.

It is likely that other phytochemical classes may also contribute to the growth inhibitory properties of these extracts. Our qualitative phytochemical screening studies indicated that tannins were present in the A. cearulea leaf extracts in low to moderate levels. Many studies have reported potent growth inhibitory activities for a number of tannin compounds. Gallotannins have been reported to inhibit the growth of a broad spectrum of bacterial species ${ }^{30}$ through a variety of mechanisms including binding cell surface molecules including lipotoichoic acid and proline-rich cell surface proteins $s^{31-32}$ and by inhibiting glucosyltransferase 
Mpala, et al.: A. caerulea inhibits bacterial growth

enzymes. ${ }^{33}$ Elligitannins are also highly potent inhibitors of bacterial growth, with MIC values as low as $62.5 \mu \mathrm{g} / \mathrm{mL}^{30,32}$ Ellagitannins have also been reported to function via several antibiotic mechanisms including interaction with cytoplasmic oxidoreductases and by disrupting bacterial cell walls. ${ }^{31,33}$ Thus, it is likely that $A$. cearulea leaf tannins may contribute to the inhibition of bacterial growth reported in our study. Triterpenoids were also detected in low to moderate levels in the inhibitory extracts. Many terpenoids have very good antibacterial activity ${ }^{30}$ and it is therefore likely that these compounds may also contribute to the growth inhibitory properties reported here.

Our findings also demonstrate that all of the A. cearulea leaf extracts were nontoxic towards Artemia franciscana nauplii, with $24 \mathrm{~h} \mathrm{LC}_{50}$ values substantially $>1000 \mu \mathrm{g} / \mathrm{mL}$. Extracts with $\mathrm{LC}_{50}$ values $>1000 \mu \mathrm{g} / \mathrm{mL}$ towards Artemia nauplii are defined as being nontoxic. ${ }^{19}$ Whilst our preliminary toxicity studies indicate that these extracts may be safe for therapeutic use, studies using human cell lines are required to further evaluate the safety of these extracts. Whilst these studies have demonstrated the potential of the A. cearulea leaf extracts in the development of future antibiotic chemotherapeutics for the prevention and treatment of urinary tract infections, autoimmune diseases (particularly rheumatoid arthritis and ankylosing spondylitis) and some gastrointestinal and skin diseases, more work is required to isolate the inhibitory components and determine the mechanism of inhibition.

\section{CONCLUSION}

The results of this study demonstrate the potential of the A. cearulea leaf extracts as inhibitors of pathogenic bacteria growth. Furthermore, their lack of toxicity indicates than they are safe for internal as well as topical treatments. Further studies aimed at the purification and identification of bioactive components are needed to examine the mechanisms of action of these agents.

\section{ACKNOWLEDGEMENT}

The authors are grateful to Philip Cameron for providing the plant material used in this study and to Michelle Mendell and Jane Gifkins for the gift of the clinical isolate bacterial strains. Financial support for this work was provided by the Environmental Futures Research Institute and the School of Natural Sciences, Griffith University, Australia.

\section{CONFLICT OF INTEREST}

The authors report no conflicts of interest.

\section{ABBREVIATIONS}

DMSO: Dimethyl sulfoxide; $\mathbf{L C}_{50}$ : The concentration required to achieve $50 \%$ mortality; MIC: minimum inhibitory concentration.

\section{REFERENCES}

1. Australian Tropical Rainforest Plants. Alipinia caerulea. http://keys.trin.org.au/ key-server/data/0e0f0504-0103-430d-8004-060d07080d04/media/Html/taxon/ Alpinia_caerulea.htm. Cited 9/6/2016

2. Tapsell LC, Hemphill I, Cobiac L, et al. Health benefits of herbs and spices: the past, the present, the future. Med J Aust. 2006;185(4):S1-S24

3. Anand P, Sundaram C, Jhurani S, et al. Curcumin and cancer: an "old-age" disease with an "age-old" solution. Cancer Lett. 2008;267(1):133-64.

4. LeStrange R. A history of herbal plants. Angus and Robertson. 1977.

5. Maen A, Cock IE. Inhibitory activity of Australian culinary herb extracts against the bacterial triggers of selected autoimmune diseases. Pharmacognosy Communications. 2015;5(2):130-9. DOI: 10.5530/pc.2015.2.4

6. He ZH, Gilli C, Yue GGL, et al. Anti-angiogenic effects and mechanisms of zerumin A from Alpinia caerilea. Food Chemistry. 2012;132(1):201-8.

7. Sivasothy $Y$, Ibrahim $H$, Paliany AS, et al. Pahangensin $A$ and $B$, two new antibacterial diterpenes from the rhizomes of Alpinia pahangensis Ridley. Bioorganic and Medicinal Chemistry Letters. 2013;23(23):6280-5.
8. Arkhipov A, Sirdaarta J, Rayan P, et al. An examination of the antibacterial, antifungal, anti-Giardial and anticancer properties of Kigelia africana fruit extracts. Pharmacognosy Communications. 2014;4(3):62-76. DOI: 10.5530/ pc.2014.3.7

9. Kalt FR, Cock IE. Gas chromatography-mass spectroscopy analysis of bioactive Petalostigma extracts: Toxicity, antibacterial and antiviral activities. Pharmacognosy Magazine. 2014;10(Suppl 1):S37-49. DOI: 10.4103/0973-1296.127338

10. Vesoul J, Cock IE. The potential of Bunya nut as an antibacterial food agent. Pharmacognosy Communications. 2012;2(1):72-9. DOI: 10.5530/pc.2012.1.13

11. Courtney R, Sirdaarta J, Matthews B, et al. Tannin components and inhibitory activity of Kakadu plum leaf extracts against microbial triggers of autoimmune inflammatory diseases. Pharmacognosy Journal. 2015;7(1):18-31. DOI: 10.5530/pj.2015.7.2

12. Winnett $\mathrm{V}$, Boyer $\mathrm{H}$, Sirdaarta J, et al. The potential of Tasmannia lanceolata as a natural preservative and medicinal agent: Antimicrobial activity and toxicity. Pharmacognosy Communications. 2014;4(1):42-52. DOI: 10.5530/pc.2014.1.7

13. Wright MH, Matthews B, Arnold MSJ, et al. The prevention of fish spoilage by high antioxidant Australian culinary plants: Shewanella putrefaciens growth inhibition. International Journal of Food Science and Technology. 2016. DOI: $10.1111 /$ ijfs. 13026

14. Sautron C, Cock IE. Antimicrobial activity and toxicity of Syzygium australe and Syzygium leuhmanii fruit extracts. Pharmacognosy Communications. 2014;4(1):53-60. DOI: 10.5530/pc.2014.1.8

15. Hart C, llanko P, Sirdaarta J, et al. Tasmannia stipitata as a functional food/natural preservative: Antimicrobial activity and toxicity. Pharmacognosy Communications. 2014;4(4):33-47. DOI: 10.5530/pc.2014.4.4

16. Cock IE. Antimicrobial activity of Acacia aulacocarpa and Acacia complanta methanolic extracts. Pharmacognosy Communications. 2012;2(1):66-71. DOI: 10.5530/pc.2012.1.12

17. Cock IE. Assessment of the toxicity of selected Australian native plant extracts using the Artemia franciscana nauplii bioassay. Internet Journal of Toxicology. 2008;5(2):2

18. Ruebhart DR, Wikramasinghe WA, Cock IE. Protective efficacy of the antioxidants vitamin $\mathrm{E}$ and Trolox against Microcystis aeruginosa and microcystin-LR in Artemia franciscana nauplii. Journal of Toxicology and Environmental Health Part A. 2009;72(24):1567-75

19. Cock IE, Ruebhart DR Comparison of the brine shrimp nauplii bioassay and the ToxScreen-II test for the detection of toxicity associated with Aloe vera (Aloe barbadensis Miller) leaf extract. Pharmacognosy Research. 2009;1(2): 98-101.

20. Cock IE, van Vuuren SF. Anti-Proteus activity of some South African plants: Their potential for the prevention of rheumatoid arthritis. Inflammopharmacology. 2014;22(1):23-36. DOI: 10.1007/s10787-013-0179-3

21. Ebringer $A$, Rashid T. Rheumatoid arthritis is an autoimmune disease triggered by Proteus urinary tract infection. Clinical and Developmental Immunology. 2006;13(1):41-8

22. Cock IE, Vuuren SFV. The potential of selected South African plants with antiKlebsiella activity for the treatment and prevention of ankylosing spondylitis. Inflammopharmacology. 2015;23(1):21-35. DOI: 10.1007/s10787-014-0222-z

23. Ebringer A, Rashid T, Wilson $C$, et al. Ankylosing spondylitis as an auto-immune disease linked to intestinal Klebsiella infection: prospects for a new therapeutic approach. Current Rheumatology Reviews. 2006;2:55-68.

24. Mohanty S, Cock IE. Evaluation of the antibacterial activity of Mycaria caulifloria methanolic leaf and fruit extracts. The Internet Journal of Microbiology. 2009;7(2).

25. Cock IE, Vuuren SFV. South African food and medicinal plant extracts as potential antimicrobial food agents. Journal of Food Science and Technology. 2015;52(11):6879-99. DOI: 10.1007/s13197-015-1806-3

26. Cock IE, Kukkonen L. An examination of the medicinal potential of Scaevola spinescens: Toxicity, antibacterial and antiviral activities. Pharmacognosy Research. 2011;3(2):85-94. DOI: 10.4103/0974-8490.81955

27. Vesoul J, Cock IE. An examination of the medicinal potential of Pittosporum phylliraeoides: Toxicity, antibacterial and antifungal activities. Pharmacognosy Communications. 2011;1(2):8-17. DOI: 10.5530/pc.2011.2.3

28. Cock IE. Antibacterial activity of selected Australian native plant extracts. Internet Journal of Microbiology. 2008;4(2):1-8.

29. Cock IE. The phytochemistry and chemotherapeutic potential of Tasmannia lanceolata (Tasmanian pepper): A review. Pharmacognosy Communications. 2013;3(4):13-25. DOI: 10.5530/pc.2013.4.3

30. Buzzini P, Arapitsas P, Goretti M, et al. Antimicrobial activity of hydrolysable tannins. Mini-Reviews in Medicinal Chemistry. 2008;8(12):1179-87.

31. Wolinsky LE, Sote EO. Isolation of natural plaque-inhibiting substances from 'Nigerian chewing sticks'. Caries Research .1984;18(3):216-25.

32. Hogg SD, Embery G. Blood-group-reactive glycoprotein from human saliva interacts with lipoteichoic acid on the surface of Streptococcus sanguis cells. Archives in Oral Biology. 1982;27(3):261-8.

33. Wu-Yuan CD, Chen CY, Wu RT. Gallotannins inhibit growth, water-soluble glucan synthesis and aggregation of Streptococci mutans. Journal of Dental Research. 1988;67(1):51-5. 
PICTORIAL ABSTRACT

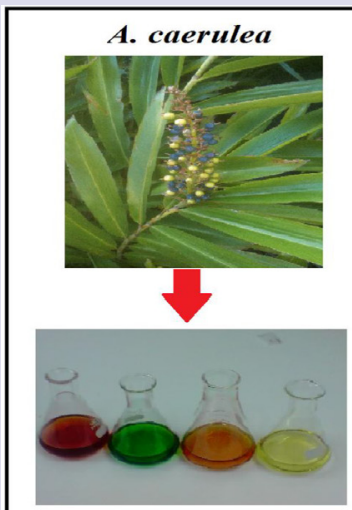

Extracts

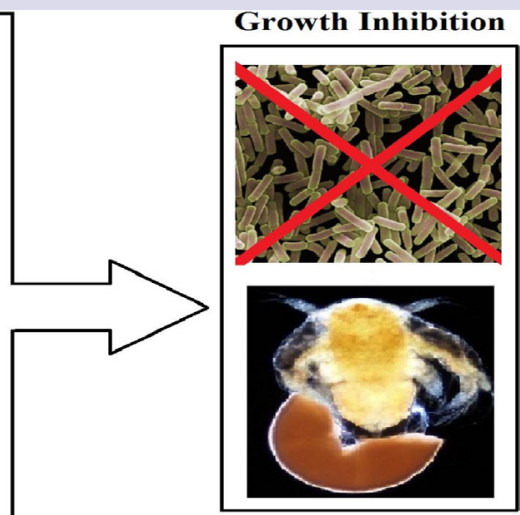

Non-toxic

\section{SUMMARY}

- Methanolic and aqueous $A$. caerulea leaf extracts inhibited the growth of a range of gram positive and gram negative bacterial species.

- The methanolic and aqueous extracts were potent inhibitors of S. marcenscens growth, with MICs of 188 and $405 \mu \mathrm{g} / \mathrm{mL}$ respectively.

- P. mirabilis and K. pneumoniae were also highly susceptible to the methanolic and aqueous extracts (MICs in the range $750-1250 \mu \mathrm{g} / \mathrm{mL}$ ).

- The growth of $B$. cereus, $S$. aureus and $S$. epidermidis were also inhibited by the methanolic and aqueous extracts, albeit with higher MIC values.

- All A. caerulea leaf extracts were nontoxic.

\section{ABOUT AUTHORS}

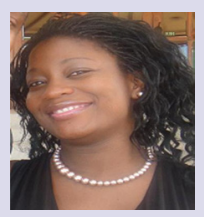

Ms Getmore Chikowe completed her BSc at Griffith University in life sciences. Following graduation, she undertook a research project in Dr lan Cock's laboratory in the School of Natural Sciences at Griffith University. The project examined the growth inhibitory properties of a variety of Australian native plants against an extensive panel of bacterial pathogens.

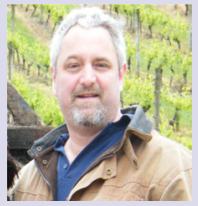

Dr lan Cock leads a research team in the Environmental Futures Research Institute and the School of Natural Sciences at Griffith University, Australia. His research involves bioactivity and phytochemical studies into a variety of plant species of both Australian and international origin, including Aloe vera, South Asian and South American tropical fruits, as well as Australia plants including Scaevola spinescens, Pittosporum phylliraeoides, Terminalia ferdinandiana (Kakadu plum), Australian Acacias, Syzygiums, Petalostigmas and Xanthorrhoea johnsonii (grass trees). This range of projects has resulted in nearly 200 publications in a variety of peer reviewed journals.

Ms Lindiwe Mpala completed her BSc at Griffith University in Life Sciences. Following graduation, she undertook a research project in Dr lan Cock's laboratory in the School of Natural Sciences at Griffith University. The project examined the growth inhibitory properties of a variety of Australian native plants against an extensive panel of bacterial pathogens. 